American Journal of Economics and Business Administration 3 (3): 506-510, 2011

ISSN 1945-5488

(C) 2011 Science Publications

\title{
Inter Local Government Capital Budget Execution Comparism
}

\author{
F. Olurankinse \\ Department of Accounting, Faculty of Social and Management Sciences, \\ Adekunle Ajasin University, Akungba, Akoko
}

\begin{abstract}
Problem statement: Unrealistic capital budgeting has long been the bane of social economic development in Nigeria and of course, at the local government level. Local governments are established with specific functions to assist the state and federal government to bring about effective rural development and good governance at the grassroots level. Approach: Both fiscal and physical evaluation of the performances of this tier of government in ondo state reveals a low level of performance both in terms of physical development and provision of social welfare services require to enhance the quality of life at the grassroots level. Those responsible for the management of funds at this level ascribed their poor performances to underfunding. This study therefore aims at finding out if truly this claim of underfunding is actually the cause of their poor performance. The study will look at the total capital budget allocation to some selected local governments visa is their actual spending. A sample of nine local governments was selected using random sampling technique based on their settlement pattern. Results: A comparative analysis was done to determine which local government has the largest rate of capital budget execution. The result shows that the local government with the least capital allocation has the largest rate of capital budget execution. Conclusion: The study concludes that the performance of any local government is not a function of availability of huge capital funds but ability to utilize the scarce resources to achieve optimum result.
\end{abstract}

Key words: Capital budget, execution rate, local government, capital expenditure, capital budget execution, social amenities, scarce resources, budgeting techniques, major structure, investment decision, economic realities

\section{INTRODUCTION}

The rate of economic development in the Local government areasof Ondo state has been relatively slow and needs to be accelerated. Local Government is part of the general government system and exists to supplement and extend the federal government principally because it exits to bring the federal government closer to the people and make its impact felt in all the nooks and crannies of the area. To this end, the local government acts as the lens or binoculars through which people view and judge the federal and state governments and its activities. It is also a medium through which the yearnings of the people at the grassroots are communicated to other levels of government (Dubnick, 2002).

The elevation of local government to a third tier of government following the 1976 local government reform with accompanying increase in functional responsibilities brings to greater forms the need to address the issues of capital expenditure budgeting, allocation and execution. The term capital means the funds employed to finance fixed and long term assets. Capital expenditure is expenditure that generates cash flows/benefits expected to extend beyond one year (Elumilade et al., 2006). It involves making investments decisions concerning the financing of capital projects such as provision of infrastructural and social amenities which are necessity of life. Making a good investment decision that will better the life of the rural dweller is very germane since funds are scarce and human wants are unlimited. Therefore to utilize the available scarce financial resources to enhance better performance, Capital budgeting decision is one of the requirements, if properly applied, can accelerate development at the grassroots.

Review of related literature: Today, because of scarce resources, the management of money is more important than ever for public and private entities, budgeting plays an enormous role in controlling operations efficiently and effectively. Budget and budgeting are concepts traceable to bible days, precisely the days of Joseph in Egypt. It was reported that nothing was given out of the treasure without a written order. History has it that Joseph budgeted and store grains which lasted the Egyptians throughout the seven years of famine 
Bible. Budget was first introduced in the 1920s as a tool to manage cost and cash flows in large industrial organization.

States that it was during the 1960s that companies began to use budgets to dictate what people needed to do. In the 1970s performance improvement was based on meeting financial targets rather than effectiveness.

Budgeting in business organization was formally associated with the advent of industrial capitalism for the industrial revolution of the eighteen century, which presented a challenge for industrial management.Glautier and Underdown (2001) state that "the emergence of scientific management philosophy with its emphasis on detailed info' as a basis for making decision provided a tremendous impetus for the development of management accounting and indeed budgeting techniques.

\section{MATERIALS AND METHODS}

The practice of budgeting in government as it is now understood originated in the central government of Great Britain. it later develops gradually as a results of parliaments struggle to obtain control over the finance of the crown. In 1217, it was declared in Magna Charta that no cottage or aid shall be imposed in the Kingdom unless by the common council of realm (Omolehinwa, 2003).

Budget cycle: Budgeting is a cyclical decision making process. The budget process offers the potentials of government programmers and their costs in the light of long range objectives. According to Bello-Imam (1996), budgeting involved projected detailed plan of action for the use of resources that links financial resources and human behaviors together to accomplish an organizational objectives which has to do with the future and thus calls for serious coordination and articulation. The budgeting process is a cycle comprised of two phases: the planning phase and the control phase. The planning phase identifies the goals to be attained during the fiscal year and the financial plan (budget) necessary to achieve them. The control phase focuses on actual performance towards achieving the plan. It involves implementation, monitoring and control functions. The control phase emphasizes a comparison between the budget and the actual revenue and expense activity as recorded in the financial statement and display on the monthly statements. When actual revenue and expense varies from the plan articulated by the budget, the control phase will then include corrective action. Corrective action might involve adjusting the budget to reflect the actual financial activity, adjusting revenue projections and collections, or adjusting expenditures.
The Fig. 1 shows the overall budgeting circle. The arrows going back and front from one activity to another indicate a process that moves, not away, but to and fro. This is a considerable amount of re-appraising, redeveloping and re-evaluating at every stage. It is a continuing and dynamic process that looks to the future by evaluating the present. The comparison of results to expectation is a step in planning for the next cycle of business activity. The major structure of goal setting and planning is contained in the master budget.

Classification of budget: The Mackay (1998) classifies budgets into two broad categories. According to this body, "a traditional form of budgeting consists of separate estimates of recurrent revenue and expenditures and capital spending". The recurrent budget is concerned with the regular operation of services, including salaries, pension contributions, the purchase of short-life equipment, the cost of routine repairs and maintenance and the servicing of long term debt. The capital budget is largely concerned with the creation of long-term assets" One test of a capital outlay is whether it adds substantially to the value of the assets of government (Herbert et al., 1987). It is one most appropriate means for planning for capital projects; supported by a capital improvement program. The term capital improvement refers to projects of relatively large size, nature and/or long life usually a minimum of fifteen to twenty years. Such expenditures are designed to provide new or additional governments facilities for public services. Since the objective is to provide major public facilities that have a relatively long life within the limits of available public resources, capital budgeting should involve planning, programming and formulation of policies in terms of the desired levels of public service to be provided-goals and objectives. These goals and objectives should be related to population and economic levels and economic trends and projections to ascertain future demands for public services and facilities.

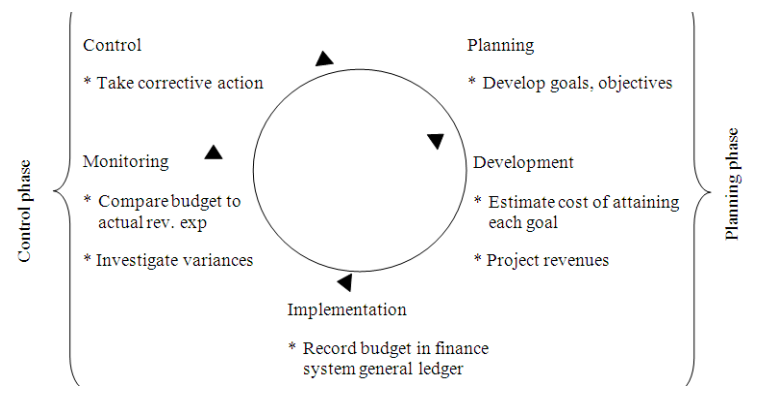

Fig. 1: Budget Cycle Source: University of Colorado Management Guide 


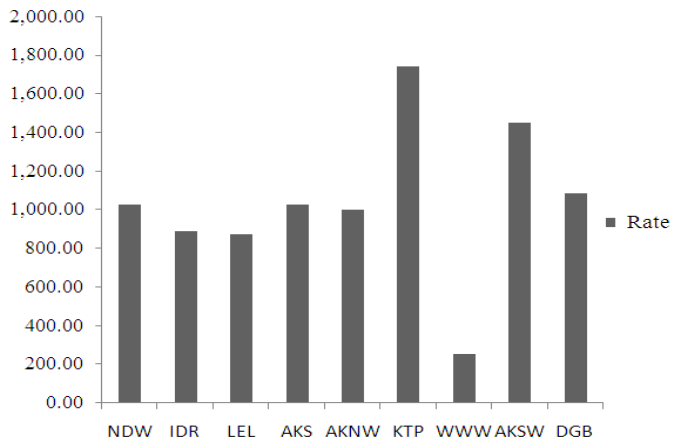

(a)

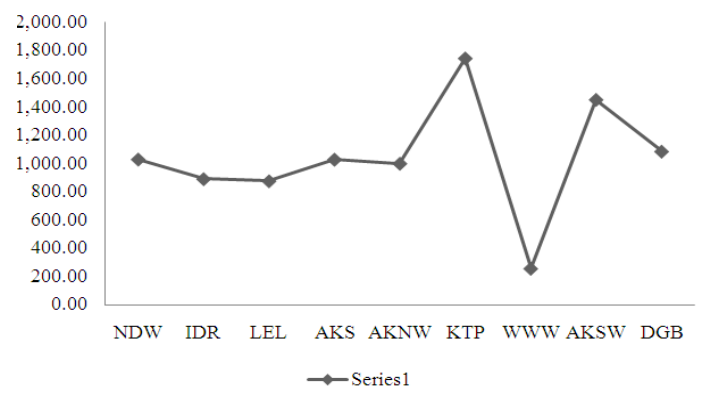

(b)

Fig. 2: Graph of inter local government capital budget allocation

The above figure shows the processes involved in budgeting commencing from the planning stage to the stage of implementation.

The Fig. 2a and b represented above shows the total capital budgeted to each local government for the period covered in this study. The figure shows that Okitipupa (KTP) received the highest allocation while Owo (WWW) received the least.

The need for programming capital improvements arises from the limited fiscal resources available to any level of government. Programming should be based on a system of priorities tied to the goals and objectives set forth in the planning phase.

Causes of adverse budget performance: Generally, the followings may limit the success of budgeting in any socio-technical system.

The Fig. 3a and $b$ represented above shows the rate of capital project execution among the local governmenst.The figure shows that Owo local government having the least allocation as shown in Fig. 2 posses the highest rate of project execution.

Lack of full participation among the council members and heads of Department in the course of preparing budget, there is a poor participation from councilors and head of Departments. They are either not brought in during preparation or briefed after preparation by the budget officer.

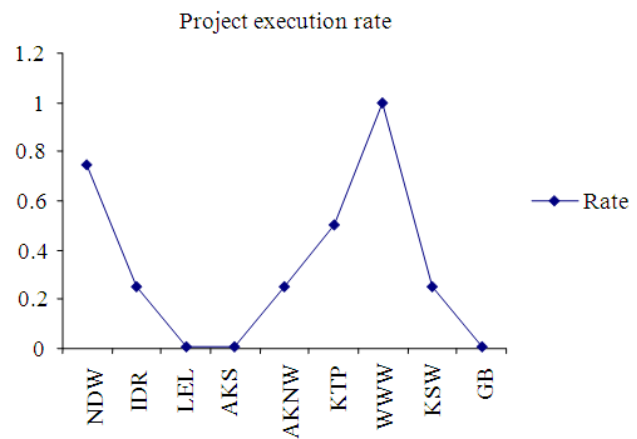

(a)

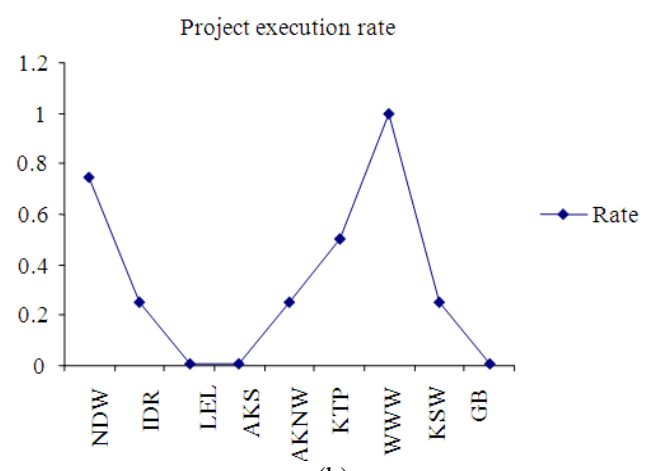

(b)

Fig. 3: Graph of inter local government capital project execution rate comparison

Lack of budget review once the budget is passed, it is kept on the shelf as historical document. It is never consulted or reviewed after preparation

Budget being superimposed some expenditure items and revenue targets are imposed by the state officers during draft estimate defense. Even, when the local governments are trying to be realistic in their estimate, budget targets are imposed on them by supervising state officers.

Lack of designated budget officers in the local governments. The treasurer's to the local governments, who double as budget officers, is too busy for the job therefore there is no enough time for them to do a thorough preparation and monitoring of budget

Extra budgetary affairs government officials are in habit of incurring expenditure as the need arises without any recourse to budgetary provisions. Most of this expenditure is ordered from the above either by state or federal directive to sponsor some people for seminar or to purchase certain items for local government.

Variances are frequently made due to changing circumstances, poor forecasting or general uncertainties resulting fromlack of knowledge and inexperience on the part of management. 
Am. J. of Economics and Business Administration 3 (3): 506-510, 2011

Budgets are developed round existing organizational structures and departments, which may be inappropriate for current conditions and may not reflect the underlying economic realities.

The inherent lags and delays in a system may make the budgets and resulting variances of little value as a guide to current operations.

In government specifically is of the view that "of all the characteristics of budget systems in many economies that conspire against performance, perhaps the most crucial" include:

- Extra budgetary funds

- Earmarked funds

- Unpredictability and

- Unreliable information

The data used for this study, mainly secondary, were obtained from the annual financial statements and approved budget estimates of each local government for the twelve years period of study and are presented in Table 1. It is to be noted that the nine (9) local governments sampled from the population are presented separately. A comparative analysis of capital budgeting is made at the end of the paper. The following local government areas of Ondo State were sampled:

- $\quad$ Ondo West Local Government Area (NDW)

- Idanre Local Government Area (IDR)

- Ile-Oluji Local Government Area (LEL)

- $\quad$ Akure South Local Government Area (AKS)

- Akoko Northwest Local Government Area (AKNW)

- $\quad$ Okitipupa Local Government Area (KTP)

- Owo Local Government Area (WWW)

- Akoko Southwest Local Government Area (AKSW)

- Odigbo Local Government Area (DGB)

Analysis of data was carried out using descriptive statistics such as mean, median and standard deviation.

\section{DISCUSSION}

In order to bring the discussion to a reasonable conclusion, the following questions are answered:

- Which of the local government has the largest capital budget allocation within the specified period of time?

- Which of the local government has the highest rate of executing capital projects within the specified period of time?

Table 1: Inter Local Government Capital budget allocation

\begin{tabular}{lr}
\hline LG & CBA (N million) \\
\hline NDW & $1,028.1700$ \\
IDR & 889.7900 \\
LEL & 874.9460 \\
AKS & 1027.4560 \\
AKNW & 998.9733 \\
KTP & 1742.4640 \\
WWW & 256.5339 \\
AKSW & 1450.4060 \\
DGB & 1084.2890 \\
\hline
\end{tabular}

Sources: Researcher's computation 2009

Table 2: Inter Local Government capital budget execution Rate

\begin{tabular}{ll}
\hline LG & Rate \\
\hline NDW & 0.75 \\
IDR & 0.25 \\
LEL & 0.01 \\
AKS & 0.01 \\
AKNW & 0.25 \\
KTP & 0.50 \\
WWW & 1.00 \\
KSW & 0.25 \\
GB & 0.01 \\
\hline
\end{tabular}

Sources: Researcher's Computation 2009

The answer to the first question is presented in Table 1 where a comparison is made of capital budget allocation measures in Million Naira among the nine local governments. The Table shows that Okitipup a local government has the largest capital budget allocation, followed by Akoko South West and so on. Owo Local government has the least relative capital budget during the period covered by this study.

Table 2 answers the second question. According to the Table Owo local government with the least capital budget has the highest project execution rate. Ondowest (NDW) is above average in terms of project execution. Okitipupa local government with the highest capital budgeting do not perform to expectation in terms of project execution. Idanre, Akoko North West and Akoko South West have the same project execution rate (0.2), below average. In short only Owo local government has project execution commensurate with its capital budgeting; Ondo West is also above average. Others were below average; Infact, Ile-Oluji, Akure South and Odigbo have almost zero rate of significant project execution.

\section{CONCLUSION}

The paper tried to look at capital budget allocation to each of the local government in Ondo state and their rates of execution. Budget is seen as the most important economic policy tool of any government. A public sector budget is used as an instrument to allocate public resources toward achieving some public value. The 
local government budget is thus the fundamental indicator of what government proposes to do and what objectives it pursues. Of the nine local governments studied, it was shown that only one local government, specifically, Owo local government with the least capital budget allocation has the highest project execution rate commensurate with its capital budget. It can therefore be concluded that the performance of any local government does not rest squarely on availability of huge capital fund.

In the light of the finding, the following steps need to be considered in order to achieve the most desirable level of capital expenditure effectiveness at the local government level:

- There is need for a strong and reliable database. This is required at every level of planning be it short, medium or long term. Meaningful budgeting requires having access to a reliable and comprehensive data. No wonder the state government has in the year 2010, directed all the eighteen local governments to establish a department of statistics to be headed by a statistician for the purpose of making available relevant information that are required for effective planning and budgeting

- While it is true that budgeting exercise involves taking into consideration the submissions of various department and units in government, the budgeting process should not be reduced to merely aggregating such submissions into a whole or a single budget. There is need for harmonization of policies and projections, first, between various government departments and units to ensure internal consistency and, secondly, to avoid duplication of expenditure so that overall targets are within achievable units

- $\quad$ There is need for participatory budgeting where all the stake holders and budget beneficiaries such as departments, units, the public, private sector, media and so on constituting the local government are allowed to participate and make their own representation

- For effective budget implementation, there must be consistency in government policies over a given period of time as policy inconsistency adversely affected budget effectiveness

- To ensure proper budget effectiveness, regular monitoring and evaluation of programmes and projects is critical. It is necessary to develop an appropriate mechanism for monitoring the budget in order to enhance effectiveness in the level of budget performance and accomplishment

\section{REFERENCES}

Bello-Imam, I.B., 1996. Local Government in Nigeria: Evolving a Third-Tier of Government. 1st Edn., Heinemann Educational Books, Nigeria, ISBN: 9789781293399, pp: 218.

Dubnick, M.J., 2002. Seeking salvation for accountability. Proceedings of the Prepared for delivery at the 2002 Annual Meeting of the American Political Science Association, Aug. 29Sep. 1, American Political Science Association, Boston, pp: 1-28.

Elumilade, D.O., T.O. Asaolu and A.O. Ologunde, 2006. Capital Budgeting and Economic Development in the Third World: The Case of Nigeria. Int. Res. J. Finance Econ., 136-152.

Glautier, M.W.E. and B. Underdown, 2001. Accounting Theory and Practice. 7th Edn., Financial Times Prentice Hall, Harlow, ISBN: 9780273651611, pp: 716.

Herbert, L., L.N. Killough and A.W. Steiss, 1987. Accounting and Control for Governmental and other Nonbusiness Organizations. 1st Edn., McGraw- Hill Inc., New York, ISBN: 9780070283169, pp: 666.

Mackay, K., 1998. Public Sector Performance. 1st Edn., Independent Evaluation Group, World Bank, ISBN: 9781602440692.

Omolehinwa, E., 2001. Government Budgeting in Nigeria. 1st Edn., Pumark Nigeria Limited, Agege, Lagos, ISBN: 9789782049421, pp: 210. 